PONTIFÍCIA UNIVERSIDADE CATÓLICA DO RIO DE JANEIRO

\title{
Patrocínio do Terceiro Setor no Futebol Brasileiro
}

\author{
João Cid Varela Neri Madeira
}

Trabalho de Conclusão de Curso

Centro de Ciências socials - CCS

DEPARTAMENTO DE AdMINISTRAÇÃO

Graduação em Administração de Empresas 
João Cid Varela Neri Madeira

\section{Patrocínio do Terceiro Setor no Futebol Brasileiro}

Trabalho de Conclusão de Curso

Trabalho de Conclusão de Curso, apresentado ao programa de graduação em Administração da PUC-Rio como requisito parcial para a obtenção do título de graduação em Administração.

Orientadora: Marcela Amorim

Rio de Janeiro, junho de 2017. 
"É graça divina começar bem. Graça maior é persistir na caminhada certa. Mas a graça das graças é não desistir nunca". (Dom Hélder Câmara) 


\section{Resumo}

MADEIRA, João Cid Varela Neri. Patrocínio do Terceiro Setor no Futebol

Brasileiro. Rio de Janeiro, 2017. Número de páginas 32. Trabalho de Conclusão de Curso - Departamento de Administração. Pontifícia Universidade Católica do Rio de Janeiro.

O futebol brasileiro vem apresentando grande avanço na sua gestão. Os clubes estão cada vez mais preocupados em profissionalizar a administração. Um dos grandes pilares dessa nova gestão é o investimento em marketing. Hoje, os gestores buscam diversas novas estratégias de marketing para atrair recursos para os clubes. Porém, o patrocínio master de camisa ainda é umas das maiores fontes de renda. O Patrocínio pode ser feito tanto por grandes empresas privadas que visam lucro, segundo setor, como por empresas sem fins lucrativos do terceiro setor. Entretanto, o dinamismo e a forma rentabilização são diferentes. Este trabalho tem como objeto de estudo analisar a viabilidade e rentabilidade de um clube ser patrocinado por uma empresa do terceiro setor.

\section{Palavras-chave}

Patrocínio, Gestão do Futebol, Administração, Segundo Setor, Terceiro Setor, Marketing Esportivo 


\section{Abstract}

Madeira, João Cid Varela Neri. Sponsorship of the Third Sector in Brazilian Football. Rio de Janeiro, 2017. Number of pages 32. End of Course Work Department of Administration. Pontifical Catholic University of Rio de Janeiro.

Brazilian football has shown great progress in its management, clubs are increasingly worried about professionalizing management. And one of the great pillars of this new management is the investment in marketing. Today managers are looking for new marketing strategies to attract resources to clubs, but shirt master sponsorship is still one of the largest sources of income. Sponsorship can be done both by large private companies that aim to profit, second sector, and by non-profit companies of the third sector, however the dynamism and the way monetization are different. This study aims to analyze the viability and profitability of a club sponsored by a third sector company.

\section{Key words}

Sponsorship, Football management, Management, Second Sector, Third Second, Marketing 


\section{Sumário}

1 O tema e o problema de estudo 1

1.1 Introdução ao tema e ao problema do estudo 1

1.2 Objetivo do estudo 2

1.3 Objetivos intermediários do estudo 2

1.4 Delimitação e foco do estudo 2

1.5 Justificativa e relevância do estudo 2

2 Referencial teórico 4

2.1 Marketing 4

2.2 Marketing Esportivo 5

2.3 Patrocínio 6

2.3.1 Patrocínio no mercado do futebol 8

2.3.1.1 Panorama geral 8

$\begin{array}{ll}\text { 2.3.1.2 Modelos de patrocínio } & 9\end{array}$

$\begin{array}{ll}\text { 2.3.1.3 Valores de patrocínio } & 9\end{array}$

2.3.1.4 Patrocínio no sentido contrário do senso comum 11

2.4 Outras formas de captura de receita no mercado 11

$\begin{array}{lll}2.5 & \text { Os três setores da economia } & 12\end{array}$

3 Métodos e procedimentos de coleta e de análise do Estudo 14

$\begin{array}{lll}3.1 & \text { Tipo de pesquisa } & 14\end{array}$

3.2 Fontes de informação selecionadas para coleta de dados 14

3.3 Procedimentos e instrumentos de coleta de dados 14

3.4 Formas de tratamento e análise dos dados coletados 15

$\begin{array}{ll}3.5 & \text { Limitações do Método } \\ & 15\end{array}$

4 Apresentação e análise dos resultados 16

$\begin{array}{lll}4.1 & \text { Descrição dos Resultados } & 16\end{array}$

4.1.1 Assuntos de interesse dos interrogados 16

$\begin{array}{ll}\text { 4.1.2 Relação com o futebol } & 18\end{array}$ 
4.1.3 Propostas aos entrevistados 19

4.2 Análise dos resultados 24

4.2.1 Maior apelo pelo social 24

4.2.2 Alavancagem das receitas de sócio e vendas de camisa 25

4.2.3 Patrocínio do terceiro setor é viável e rentável. 26

5 Conclusões e recomendações para novos estudos 27

5.1 Sugestões e recomendações para novos estudos 27

6 Referências Bibliográficas 28

$\begin{array}{ll}\text { Anexo } 1 & 31\end{array}$

Questionário aplicado na pesquisa e suas respostas 31 


\section{Lista de Gráficos}

Gráfico 1: Resultado da pesquisa sobre a maior paixão dos brasileiros .............. 8

Gráfico 2: Resultado da pesquisa quanto aos assuntos de interesse ............... 17

Gráfico 3: Relacionamento do público com o futebol ..................................... 18

Gráfico 4: Resultado proposta 1 ................................................................ 20

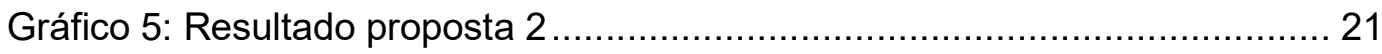

Gráfico 6: Resultado proposta 3 ......................................................... 21

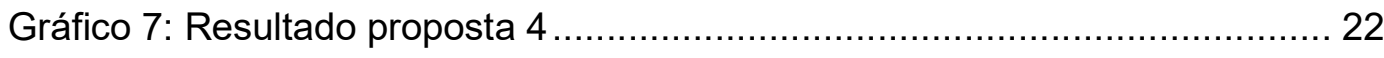

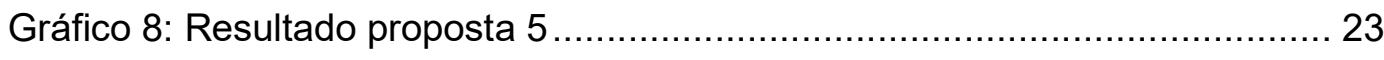

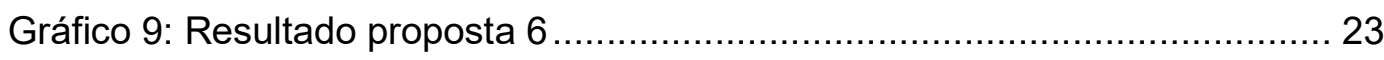

Gráfico 10: Evidências do apelo social ...................................................... 24

Gráfico 11: Resultado das ações de marketing ........................................ 25

\section{Lista de Figuras}

Figura 1: Exemplos de marketing esportivo............................................. 6

Figura 2: Mix da comunicação de marketing .............................................. 7

Figura 3: Ranking de patrocínio no futebol brasileiro em 2017 ........................ 10

Figura 4: Percentual de cada fonte de receita ............................................ 12

Figura 5: Grandes organizações do terceiro setor ..................................... 13 


\section{O tema e o problema de estudo}

\subsection{Introdução ao tema e ao problema do estudo}

O futebol brasileiro passa por uma fase de profissionalização da sua gestão. Os clubes preocupam cada vez mais em tratar sua gestão como uma empresa, proporcionado diversos benefícios, como uma saúde financeira melhor, valorização da marca e maior perspectiva para o futuro.

Decorrente dessa profissionalização, os gestores dos clubes têm estudado e praticado estratégias de marketing esportivo, que visam aumentar a receita e a exposição do time.

Dentre diversas estratégias e ferramentas de marketing, uma que é utilizada em todos os clubes de futebol e é umas das principais fontes de renda é o patrocínio. Como o futebol é um mercado de visibilidade mundial, de massa e movimenta muito dinheiro, ele é atrativo para as empresas investirem em busca de um retorno. A forma mais comum de participação das empresas no futebol é através de patrocínios, em que elas usam os times para divulgar a sua marca em troca de uma compensação financeira.

Apesar do mercado ser extremamente atrativo para as empresas investirem, vivemos um momento de crise econômica no país, o que pode afastar um pouco os investimentos ou reduzir os valores praticados.

Em tempos de crise, os clubes precisam pensar em novas formas de arrecadação, sair um pouco do senso comum praticado. E é nesse contexto $O$ problema de estudo desse trabalho.

O presente trabalho analisa uma forma diferente de patrocínio, em que o clube de futebol será patrocinado por uma empresa do terceiro setor sem que a mesma precise investir para estampar a sua marca na camisa do clube.

Portanto, esse estudo pretendente responder a seguinte pergunta: Um clube de futebol ser patrocinado por uma empresa do terceiro setor é viável e rentável? 


\subsection{Objetivo do estudo}

Esse trabalho tem como objetivo demonstrar se, com uma boa gestão de marketing, é viável e rentável para um clube de futebol um acordo de patrocínio com uma empresa do terceiro setor.

\subsection{Objetivos intermediários do estudo}

A fim de alcançar o objetivo principal, o estudo apresenta alguns objetivos intermediários no caminho:

- Analisar o momento do futebol brasileiro no que tange a gestão e marketing esportivo;

- Estudar as principais formas de patrocínio e como ele é praticado e gerido nos clubes;

- Investigar as principais fontes de receita dos clubes;

- Apurar as cifras que os patrocínios movimentam no mercado da bola;

- Realizar uma pesquisa para entender um pouco o perfil do amante de futebol e avaliar o resultado de dois tipos de patrocínio;

\subsection{Delimitação e foco do estudo}

O trabalho focou especificamente em analisar os resultados de um clube de futebol ser patrocinado por uma empresa do terceiro setor, ou seja, uma empresa sem fins lucrativos e que não irá pagar para estampar sua marca na camisa, traçando um paralelo com o patrocínio de uma grande empresa privada que visa a obtenção de lucros (segundo setor) e que paga caro para expor a sua marca.

O estudo buscou aproximar os resultados da pesquisa aplicada ao público do futebol brasileiro a conceitos de marketing, visando responder se esse modelo de patrocínio é viável e rentável ou não.

\subsection{Justificativa e relevância do estudo}

As informações que esse estudo produziu podem ser de grande valor para todos aqueles que pretendem trabalhar na área de marketing esportivo e principalmente no mercado de futebol brasileiro, pois apresenta de forma detalhada, comparativa e conceituada um dos pilares do marketing no futebol, o patrocínio. 
Além disso, os resultados do trabalho são úteis para os estudantes de administração que buscam conhecer um pouco mais sobre o tema marketing esportivo. 


\section{Referencial teórico}

A fim de ajudar na análise dos resultados da pesquisa de campo, este capítulo apresentará alguns conceitos teóricos e uma contextualização do mercado do futebol.

Inicialmente será abordada uma visão geral do conceito de Marketing, para, em seguida, apresentar com mais detalhes o marketing praticado no futebol, sendo o marketing esportivo uma de suas ferramentas estudada nesse trabalho, o patrocínio, que será analisado de forma mais profunda e abrangente, contextualizando a sua aplicação no futebol brasileiro. Este capitulo também irá falar sobre outras formas de captura de receita dos times brasileiros, o que irá ajudar em algumas análises comparativas ao longo do estudo. Por fim, e não menos importante, o último tópico é referente aos três setores da economia, que tem como objetivo apresentar as diferenças e características das organizações que pertencem a cada setor.

A compreensão dos tópicos a seguir é importante, pois irá nortear o estudo em questão.

\subsection{Marketing}

"Marketing é um processo social e gerencial pelo qual indivíduos e grupos obtêm o que necessitam e desejam por meio da criação e troca de produtos e valores." (KOTLER, 2000).

Nos dias de hoje, a preocupação e utilização do marketing está cada vez maior dentro das organizações, pois ele é uma grande ferramenta para atender os desejos e necessidades dos seus clientes. Reforçando isso, Kotler também define marketing como "a ciência e a arte de conquistar e manter clientes e desenvolver relacionamentos lucrativos com eles" (KOTLER, 2000).

Existem diversos tipos de marketing e, com o passar do tempo, vão surgindo novos, decorrentes dos avanços tecnológicos e de novos estudos. Dentre eles, destaca-se um tipo que é muito discutido nesse estudo: Marketing Social, em que sua função é motivar a responsabilidade social por meio de atitudes e ações sociais e ambientais, que buscam promover a compaixão e o 
comportamento colaborativo dos cidadãos em prol de uma sociedade melhor e mais justa. Além do bem-estar social a empresa também ganha uma exposição maior de sua marca e simpatia do público com essas atitudes (REZ, 2014).

\subsection{Marketing Esportivo}

O marketing esportivo abrange estudos e estratégias para suprir as necessidades dos consumidores do mercado esportivo, divulgar, valorizar e gerar recursos para as organizações do meio.

Segundo Antônio Afif (2000)

Marketing esportivo é uma das estratégias que utilizam o esporte para atingir suas metas. Há duas formas para definir essa prática: $1^{a}$ - marketing de produtos e serviços voltados aos consumidores que, de alguma forma, se relacionam com o esporte (camisas oficiais do time, por exemplo) e $2^{a}$ - uma estratégia que emprega o esporte como meio de divulgar produtos, sem que estes tenham ligação com atividades esportivas (patrocinadores em geral).

Marketing Esportivo abrange o marketing do esporte e o marketing através do esporte. Marketing do esporte: marketing desenvolvido dentro das instituições esportivas, que inclui produtos e serviços esportivos. Exemplos: academias, clubes, corridas, basquete, futebol. Marketing através do esporte: atividades ou produtos que fazem o uso do esporte como veículo promocional ou de comunicação. Exemplos: patrocínio esportivo, ações de ativação, produtos licenciados. (CONTURSI, 1991)

Como se observa nas imagens a seguir. 
Figura 1: Exemplos de marketing esportivo

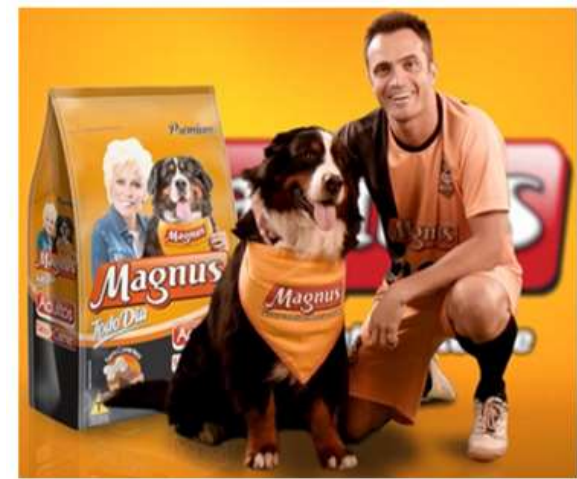

MARKETING ATRAVÉS DO ESPORTE: A empresa de alimentos para cães e gatos, Magnus, é patrocinadora master e dá o nome ao time de futsal de Sorocaba (SP).

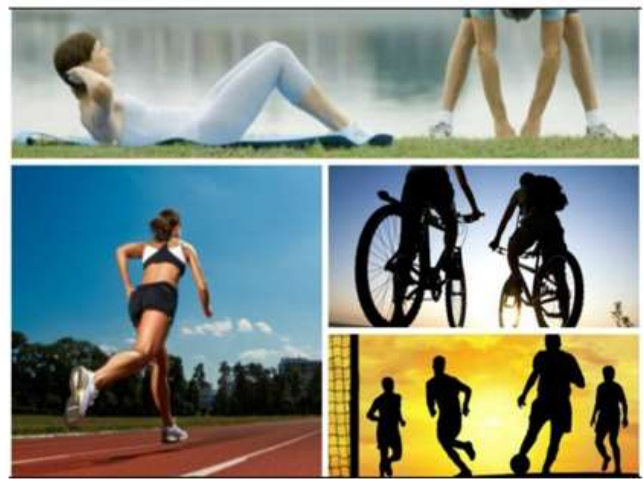

MARKETING DO ESPORTE: Campanha da Prefeitura de Cajazeiras (PB), incentivando a pratica esportiva.

Fonte: http://grandesnomesdapropaganda.com.br/anunciantes/magnus-expandeações-de-marketing-no-esportel > acesso em 07 abr. 2017

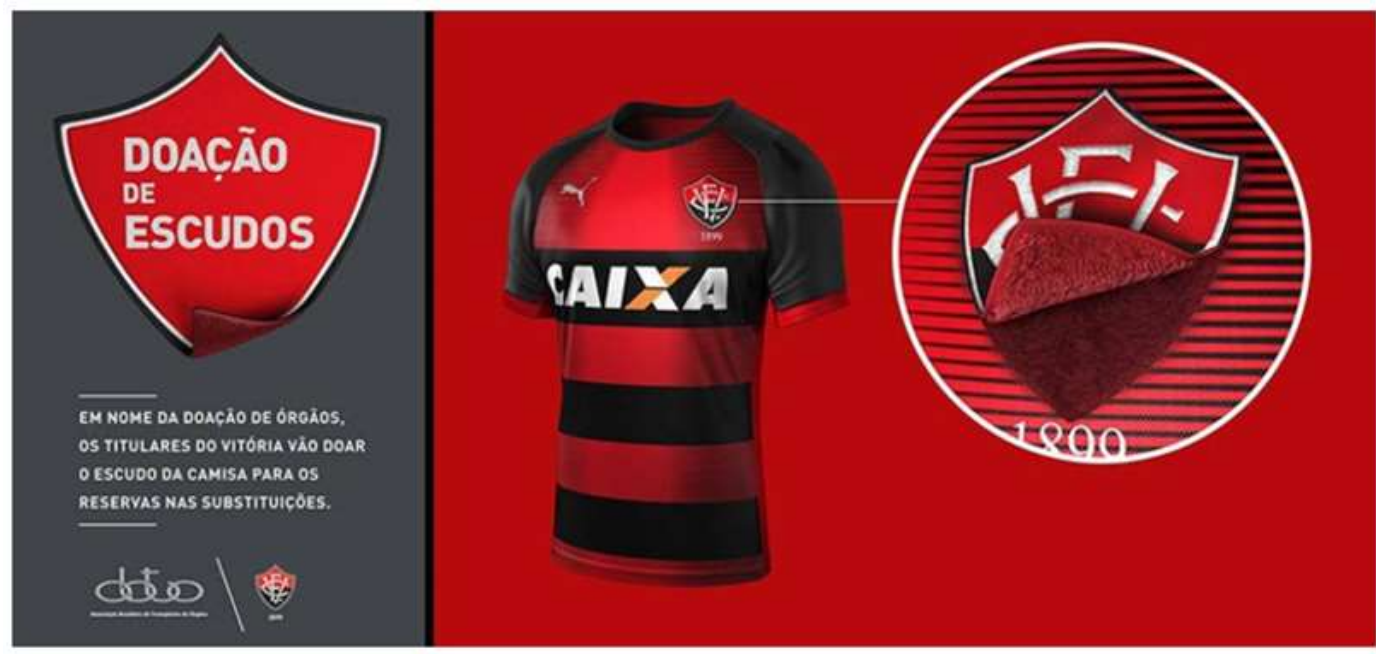

MARKETING ATRAVÉS DO ESPORTE: O clube baiano Vitória, realizou uma campanha de marketing com o objetivo de incentivar a doação de órgãos .

Fonte: ADNEWS (http://adnews.com.br/publicidade/jogadores-doarao-escudo-dovitoria-em-campo.html > acesso em 07 abr. 2017)

\subsection{Patrocínio}

Segundo Pozzi (1998), patrocínio é "provisão de recursos financeiros, humanos ou físicos por uma organização diretamente para um evento ou 
atividade em troca de uma associação direta com o mesmo" (apud SANTOS, 2010).

Analisando o patrocínio sob uma ótica mais estratégica, o autor Francisco Paulo de Melo Neto (2000) define patrocínio como

\begin{abstract}
Uma ação de marketing promocional que, ao dar suporte às demais ações do Composto Promocional, contribui para o alcance dos objetivos estratégicos de Marketing da empresa, em especial no que se refere á imagem corporativa, promoção da marca, posicionamento do produto, promoção de vendas e comunicação com clientes, fornecedores, distribuidores e demais parceiros. (apud SANTOS, 2010).
\end{abstract}

Diante disso, o patrocínio ganha cada vez mais importância no mix de marketing das organizações.

Figura 2: Mix da comunicação de marketing

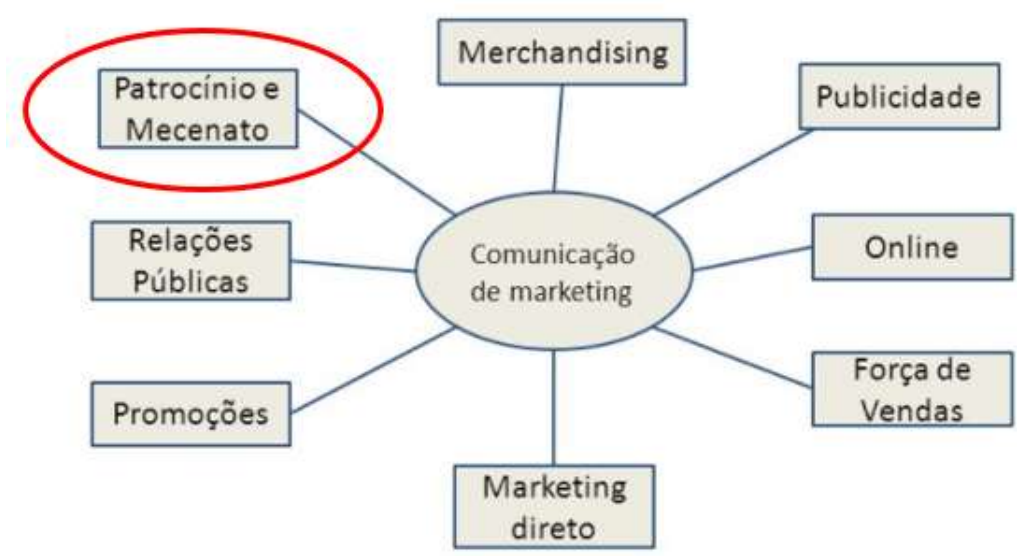

Fonte: Agrupamento de Escolas Dr. Serafim Leite

(http://slideplayer.com.br/slide/1876737/ > acesso em 5 mai. 2017) 


\subsubsection{Patrocínio no mercado do futebol}

\subsubsection{Panorama geral}

O Brasil é a terra do futebol, isso é sabido mundialmente e comprovado com pesquisas. Segundo o IBOPE, o futebol é a maior paixão dos brasileiros, com o expressivo $77 \%$ de escolha em uma pesquisa, desbancando, praia, mulheres, churrasco e até família. (Site IBOPE, 2014), como se observa no gráfico a seguir.

Gráfico 1: Resultado da pesquisa sobre a maior paixão dos brasileiros

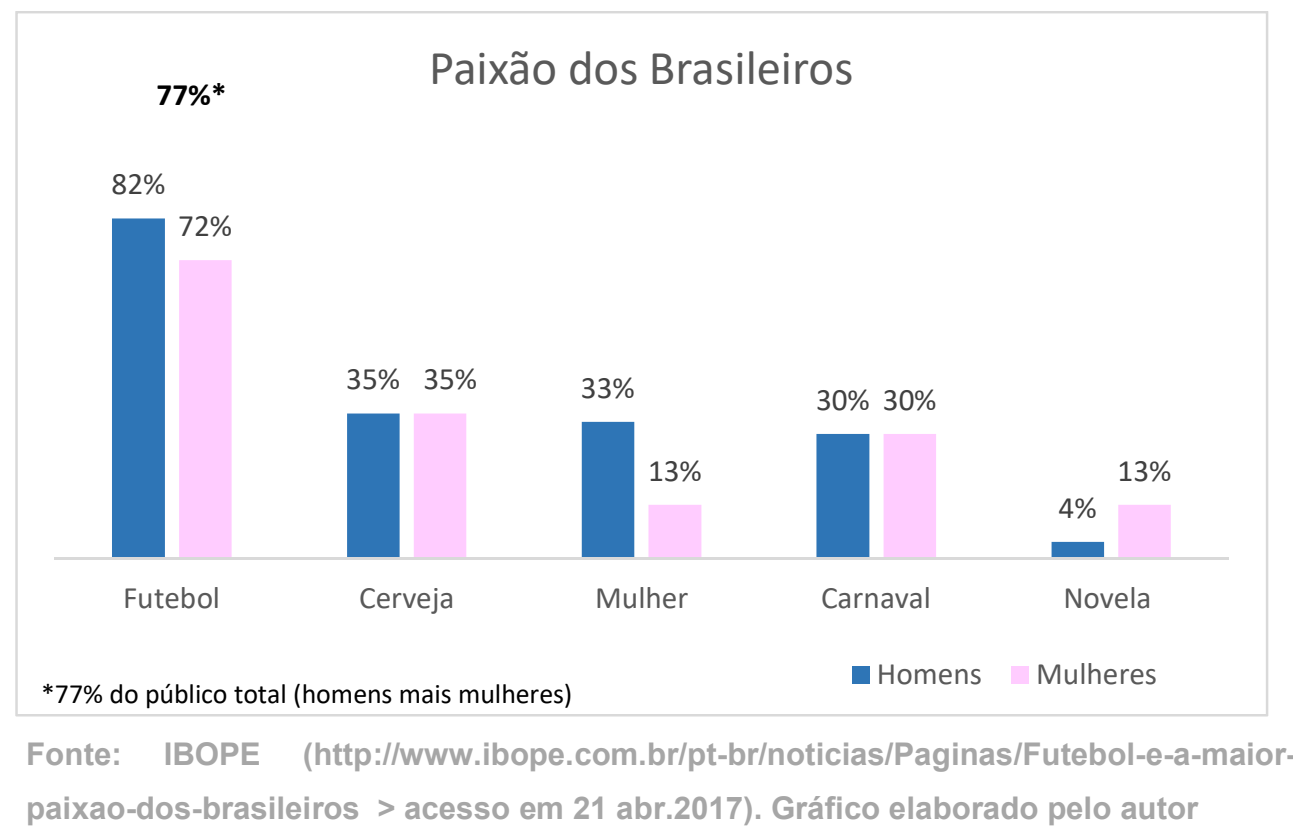

Toda essa paixão pelo futebol acaba se convertendo em grandes números que movimentam o mercado da bola. Futebol é uma das indústrias mais lucrativas do Planeta.

Em nosso país, a indústria esportiva movimenta $\mathrm{R} \$ 31$ bilhões por ano em média, o que equivale a $3,3 \%$ do PIB brasileiro, segundo a professora de marketing esportivo Clarrise Setyon (apud AMCHAM, 2012). Esse mercado bilionário, representativo e em constante crescimento, tem se tornado cada vez mais atrativo para as empresas. É aí que ganha força o marketing esportivo. 
No marketing esportivo, as empresas utilizam o patrocínio para aumentar a exposição da sua marca e o número de consumidores, através de associação a clubes, que, por sua vez, utilizam o patrocínio como fonte de receita. Além da grande exposição da marca, as empresas conseguem com os patrocínios, uma maior notoriedade entre os concorrentes, fidelização de um novo grupo de consumidores e outros benefícios.

Uma frase que representa bem o interesse das empresas em investir no futebol é: "Se o futebol importa para o público, para nós também é importante", dita por Humberto de Biase, gerente de marketing da LG (apud MOTTA, 2013). Portanto, o patrocínio é uma das ferramentas de marketing esportivo muito atraente para os clubes e empresas, pois ambos se beneficiam com o acordo.

\subsubsection{Modelos de patrocínio}

Segundo Wesley Cardia, (apud UNIVERSIDADE DO FUTEBO) existem diversos modelos de patrocínio no futebol, dentre eles, destacam-se:

- Fornecedor oficial - Empresas fornecem produtos ou serviços essenciais para o clube, como por exemplo fabricação dos uniformes e isotônicos.

- Patrocinador exclusivo - A empresa possui exclusividade na utilização e associação do clube a sua marca.

- Patrocinador oficial - Empresas dividem o espaço do clube com outras marcas de mercados distintos.

- Naming Rights - A empresa adquire o direito de associar a sua marca a um local ou evento do clube como, por exemplo, os estádios e centros de treinamento.

A escolha do modelo de patrocínio adotado pelo clube é negociada com a empresa interessada em investir de forma que seja vantajoso para ambas as partes.

\subsubsection{Valores de patrocínio}

Os valores praticados nos contratos de patrocínio podem variar por diversos fatores, tais como: duração de contrato, modalidade de patrocínio, local de exposição da marca, tamanho da marca no local exposto e valor de marca do clube. Este último é interessante se aprofundar um pouco mais, pois é uma 
variável mais complexa. O valor de marca de um clube está relacionado com a força de sua imagem, com o grau de fidelidade dos torcedores, tamanho de sua torcida e poder de influência sobre os consumidores de futebol. Portanto, quanto maior formar a marca de um clube mais ele pode exigir dos seus postulantes a patrocinadores. Como prova disso, na figura 3 , pode-se ver que os clubes brasileiros com valor de marca, que são Flamengo, Corinthians e Palmeiras, possuem os maiores contratos de patrocínio, tanto no modelo de fornecedora oficial quanto de patrocinadora oficial.

Figura 3: Ranking de patrocínio no futebol brasileiro em 2017

$$
\begin{aligned}
& \text { Maiores contratos com fornecedoras de material esportivo em 2017: } \\
& \left.1^{\circ}\right) R \$ 40,0 \text { milhões/ano - Corinthians/Nike (2016-2025) } \\
& \left.2^{\circ}\right) R \$ 35,0 \text { milhões/ano - Flamengo/Adidas (2013-2022) } \\
& \left.3^{\circ}\right) R \$ 27,0 \text { milhões/ano - São Paulo/Under Armour (2015-2019) } \\
& \left.4^{\circ}\right) R \$ 20,0 \text { milhões/ano - Palmeiras/Adidas (2017-2018) } \\
& \text { 50) } R \$ 17,0 \text { milhões/ano - Grêmio/Umbro (2015-2018) } \\
& \left.6^{\circ}\right) R \$ 14,5 \text { milhões/ano - Vasco/Umbro (2014-2017) } \\
& \left.7^{\circ}\right) R \$ 13,0 \text { milhões/ano - Botafogo/Topper (2016-2018) } \\
& \text { 70) R\$13,0 milhões/ano - Atlético-MG/Topper (2017-2020) } \\
& \left.9^{\circ}\right) R \$ 10,0 \text { milhões/ano - Cruzeiro/Umbro (2016-2019) }
\end{aligned}
$$

\section{Maiores contratos de patrocínio-master em 2017:}

10) $R \$ 72,0$ milhões - Palmeiras (Crefisa - privado)

$\left.2^{\circ}\right) R \$ 30,0$ milhões - Corinthians (Caixa)

$\left.3^{\circ}\right) R \$ 25,0$ milhões - Flamengo (Caixa)*

$\left.4^{\circ}\right)$ R 15,7 milhões - São Paulo (Prevent Senior - privado)

$\left.5^{\circ}\right) R \$ 15,0$ milhões - Santos (Caixa)

$\left.6^{\circ}\right) R \$ 12,9$ milhões - Grêmio (Banrisul)

$\left.7^{\circ}\right) R \$ 12,5$ milhões - Cruzeiro (Caixa)

70) $R \$ 12,5$ milhões - Atlético-MG (Caixa)

$\left.9^{\circ}\right) R \$ 9,0$ milhões - Vasco (Caixa)

Fonte: Site Diário de Pernambuco, 2017 (acesso em 25 abr. 2017)

Segundo o site Revista Época (2017), o futebol brasileiro faturou R\$ 5 bilhões em 2016 e desse montante $\mathrm{R} \$ 660$ milhões foram referentes a patrocínio e venda de produtos licenciados, o que comprova mais uma vez a importância dos patrocínios para a saúde financeira dos clubes. 


\subsubsection{Patrocínio no sentido contrário do senso comum}

Este é o ponto focal do estudo. Um formato de patrocínio no sentido contrário da prática comum de mercado. Nem todo patrocínio precisa ser no formato em que a empresa paga para expor a sua marca no clube, ele pode ser no sentido inverso, ou seja, o clube investe na empresa para colocar a marca dela na sua camisa. Ou ainda, o clube simplesmente sede seu espaço da camisa para a organização gratuitamente.

Este tipo de patrocínio ainda não é muito comum, pois ele não é muito estudado pelos clubes. Como o valor arrecadado diretamente com o patrocínio, dos moldes comum, representa mais ou menos $10 \%$ da receita dos clubes brasileiros, eles ficam obcecados em conseguir fechar um bom contrato de patrocínio com uma grande empresa do segundo setor, sem perder tempo analisando novas possibilidades de captura de receitas com patrocínios sem fins lucrativos de empresas do terceiro setor.

\subsection{Outras formas de captura de receita no mercado}

Segundo o estudo do especialista em gestão esportiva, Amir Somoggi, a receita com a venda de produtos licenciados e royalties das camisas oficiais gira em torno de $6 \%$ da arrecadação total do clube (SOMOGGI, 2017), o que é representativo e não muito distante da arrecadação como patrocinadores.

Sabendo disso, pode-se afirmar que um trabalho bem feito de marketing visando um incremento na venda de materiais licenciados e camisas oficiais tem potencial de gerar uma receita próxima ou até maior que um patrocínio convencional de camisa.

Somoggi (2017) também revela em seu estudo que a receita proveniente do programa de sócios dos clubes representa em média $11 \%$ do total de receitas. $\mathrm{O}$ que significa dizer que em alguns clubes se arrecada mais com sócios do que com patrocínio.

A seguir, na figura 4, está ilustrado o percentual de cada fonte de receita de 20 clubes em 2016. 
Figura 4: Percentual de cada fonte de receita

\begin{tabular}{|c|c|c|c|c|c|c|}
\hline & Direitos de TV & Jogadores & Patrocínios & Sócios & Bilheteria & Outras \\
\hline Flamengo & $58 \%$ & $2 \%$ & $13 \%$ & $16 \%$ & $8 \%$ & $2 \%$ \\
\hline Corinthians & $47 \%$ & $30 \%$ & $15 \%$ & $6 \%$ & $0 \%$ & $3 \%$ \\
\hline Palmeiras & $27 \%$ & $11 \%$ & $19 \%$ & $19 \%$ & $15 \%$ & $9 \%$ \\
\hline São Paulo & $33 \%$ & $28 \%$ & $9 \%$ & $12 \%$ & $8 \%$ & $10 \%$ \\
\hline Grêmio & $62 \%$ & $5 \%$ & $11 \%$ & $16 \%$ & $0 \%$ & $5 \%$ \\
\hline Atlético-MG & $41 \%$ & $25 \%$ & $10 \%$ & $9 \%$ & $9 \%$ & $6 \%$ \\
\hline Santos & $50 \%$ & $25 \%$ & $8 \%$ & $6 \%$ & $5 \%$ & $6 \%$ \\
\hline Fluminense & $60 \%$ & $18 \%$ & $5 \%$ & $8 \%$ & $4 \%$ & $5 \%$ \\
\hline Internacional & $53 \%$ & $7 \%$ & $12 \%$ & $22 \%$ & $4 \%$ & $3 \%$ \\
\hline Cruzeiro & $55 \%$ & $12 \%$ & $11 \%$ & $7 \%$ & $13 \%$ & $2 \%$ \\
\hline Vasco da Gama & $77 \%$ & $0 \%$ & $6 \%$ & $7 \%$ & $2 \%$ & $7 \%$ \\
\hline Atlético-PR & $34 \%$ & $20 \%$ & $5 \%$ & $15 \%$ & $5 \%$ & $21 \%$ \\
\hline Botafogo & $63 \%$ & $6 \%$ & $6 \%$ & $10 \%$ & $5 \%$ & $10 \%$ \\
\hline Bahia & $75 \%$ & $3 \%$ & $7 \%$ & $5 \%$ & $8 \%$ & $2 \%$ \\
\hline Vitória & $81 \%$ & $2 \%$ & $8 \%$ & $4 \%$ & $2 \%$ & $3 \%$ \\
\hline Coritiba & $52 \%$ & $8 \%$ & $9 \%$ & $16 \%$ & $10 \%$ & $5 \%$ \\
\hline Goiás & $65 \%$ & $29 \%$ & $4 \%$ & $4 \%$ & $2 \%$ & $0 \%$ \\
\hline Chapecoense & $41 \%$ & $8 \%$ & $9 \%$ & $9 \%$ & $3 \%$ & $29 \%$ \\
\hline Figueirense & $59 \%$ & $18 \%$ & $10 \%$ & $9 \%$ & $2 \%$ & $2 \%$ \\
\hline & \multicolumn{6}{|c|}{ Média dos 20 times } \\
\hline & Direitos de TV & Jogadores & Patrocínios & Sócios & Bilheteria & Outras \\
\hline & $51 \%$ & $14 \%$ & $11 \%$ & $11 \%$ & $7 \%$ & $6 \%$ \\
\hline
\end{tabular}

Fonte: SOMOGGI, 2017 - Site Diário Lance (acesso em 4 mai. 2017)

Uma estratégia interessante para atingir esse objetivo pode ser uma parceria de patrocínio com alguma empresa do terceiro setor, sem a necessidade de investimento por parte da organização e do clube. A imagem de uma organização sem fins lucrativos que busca promover a solidariedade social associada ao clube pode provocar uma comoção grande e maior disposição dos seus torcedores, e até mesmo de um público que não acompanha futebol, a comprar os seus produtos e camisas, além de aumentar a filiação de sócios, se feito algum programa interessante em pareceria com a organização. A gestão de marketing do clube terá um mar de possibilidades e grandes desafios com uma parceria nesse modelo.

\subsection{Os três setores da economia}

Pode-se classificar as organizações em três setores distintos, sendo a sua atividade fim e o recurso utilizado como diferenciais. 
O primeiro setor corresponde ao setor público, como por exemplo, governo do estado e prefeituras municipais, em que são organizações que utilizam o dinheiro público para realizar ações para a sociedade. Esse setor também é chamado de Estado.

O segundo setor, também conhecido como mercado, é formado pelas empresas privadas, que utilizam dinheiro privado na realização de suas atividades, visando sempre o lucro próprio.

Já o terceiro setor é composto por organizações sem fins lucrativos, que atuam em prol do bem-estar social, corrigindo problemas causados pelo setor público e privado. Esse setor utiliza dinheiro privado para realizar atividades públicas. (ESCÓSSIA, 2009)

\section{Figura 5: Grandes organizações do terceiro setor}

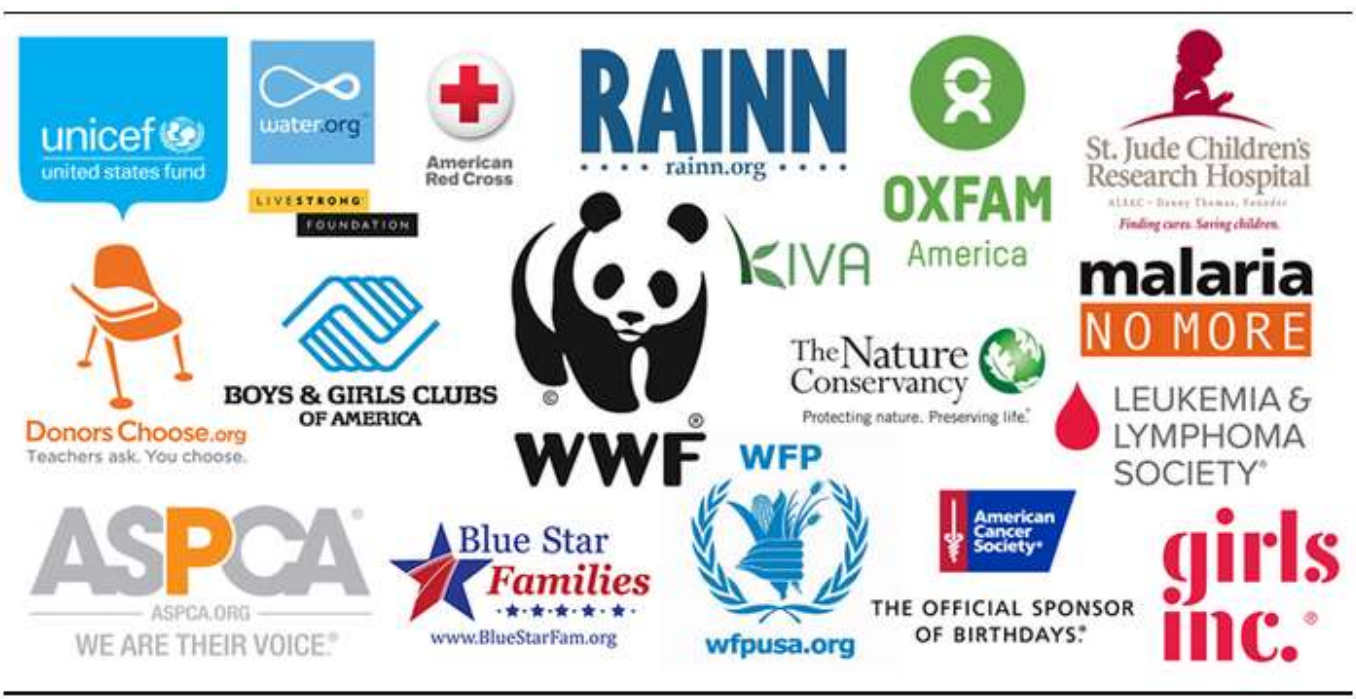

Fonte: economiasemsegredos.com (acesso em 10 mai. 2017) 


\section{Métodos e procedimentos de coleta e de análise do Estudo}

Este capítulo apresentará como o estudo foi realizado, se aprofundando no desenvolvimento e etapas da pesquisa.

\subsection{Tipo de pesquisa}

Para conseguir atingir o objetivo deste trabalho, foi realizada uma pesquisa quantitativa descritiva na forma de questionário fechado, a fim de conhecer algumas características do público alvo e estabelecer relações entre variáveis.

Esse método foi escolhido porque com ele é possível categorizar o público alvo, reconhecer atitudes e opinião e classificar preferências.

\subsection{Fontes de informação selecionadas para coleta de dados}

Os entrevistados escolhidos foram pessoas aleatórias, com uma única característica em comum obrigatória, interesse por esporte. Não teve muito critério de seleção dos entrevistados, pois para o estudo é interessante saber a opinião de públicos distintos.

Os sujeitos de pesquisa foram selecionados, de início, através da rede de amigos do elaborador da pesquisa. Posteriormente, os entrevistados pediram para amigos do seu ciclo de amizade responderem, gerando assim uma amostra considerável e uma heterogeneidade de entrevistados.

\subsection{Procedimentos e instrumentos de coleta de dados}

A pesquisa realizada, de caráter quantitativo, teve como objetivo obter informações sobre interesses, opiniões e preferências dos indivíduos e além disso medir algumas variáveis. Foi realizado um questionário de perguntas fechadas (em anexo) na ferramenta online Qualtrics.com e enviado via e-mail e rede social para pessoas que gostam de esporte. Os sujeitos de pesquisa responderam o 
questionário com as respostas que mais Ihes representavam e expressam sua opinião.

\subsection{Formas de tratamento e análise dos dados coletados}

Com informações de artigos, foi estudado o mercado atual de futebol, marketing e patrocínio, levantando valores movimentados, melhores práticas utilizadas e outras informações pertinentes ao trabalho. Depois, a partir das respostas dos questionários, foram analisadas as preferências e reações dos entrevistados sobre as situações propostas no questionário. Outro passo foi quantificar algumas informações.

O segundo passo foi fazer relações entre diversas variáveis da pesquisa de campo com outras do mercado e referencias teóricas. Com essas informações, foi possível realizar análises estatísticas e conceituais que foram fundamentais para atingir o objetivo desse estudo.

\subsection{Limitações do Método}

Assim como toda pesquisa, a utilizada nesse trabalho também teve suas restrições. Como a pesquisa de campo foi realizada na forma de questionário com perguntas fechadas, algumas limitações técnicas foram encontradas: nem todas as respostas representavam exatamente o interesse do interrogado; as opções de respostas acabam induzindo a uma resposta que não seria a mesma se fosse em um questionário aberto; e o respondente não tem ajuda do entrevistador caso tenha alguma dúvida. Outro ponto de limitação tem relação com a quantidade de perguntas, pois para não ficar um questionário muito longo e cansativo para os respondentes, foram eleitas somente 15 perguntas, o que não permite um levantamento rico de informações. 


\section{Apresentação e análise dos resultados}

\subsection{Descrição dos Resultados}

A pesquisa de campo foi realizada com o intuito de verificar se o patrocínio de uma empresa do terceiro setor, sem nenhum pagamento para estampar a sua marca na camisa do time, é viável e rentável para um clube de futebol.

O questionário foi respondido por noventa e cinco pessoas de perfis diferentes, amantes ou não de futebol.

A partir das respostas conseguimos verificar o apelo do público a causas sociais e sua reação a algumas propostas apresentadas na pesquisa.

\subsubsection{Assuntos de interesse dos interrogados}

Com relação a questões socioambientais, a pesquisa apontou que $99 \%$ do público tem algum interessa pela causa e $66 \%$ muito interesse. Portanto pode-se afirmar que hoje em dia a preocupação com o meio ambiente e o social está cada vez mais forte.

Tecnologia e inovação é outro tema que está em alta, principalmente nos mais jovens. $56 \%$ dos entrevistamos gostam muito desse tema e apenas $2 \%$ não possuem interesse algum.

O último assunto pesquisado, e não menos importante para o estudo, foi moda, tendências e marcas do momento. Assim como os demais, o público também apresentou um baixo nível de desinteresse ao tema, apenas $4 \%$. Já os entusiastas somam $42 \%$.

Esses temas foram estudados, pois a questão central da pesquisa é comparar a preferência do público a um patrocínio de uma empresa de grande nome no mercado, como a Apple ou de uma organização não governamental sem fins lucrativos, como a ONG Sonhar Acordado. 
Gráfico 2: Resultado da pesquisa quanto aos assuntos de interesse

Numa escala de 0 a 5 , onde 0 é totalmente sem interesse e 5 é extremamente interessado, qual o seu interesse por questões sociais e ambientais?

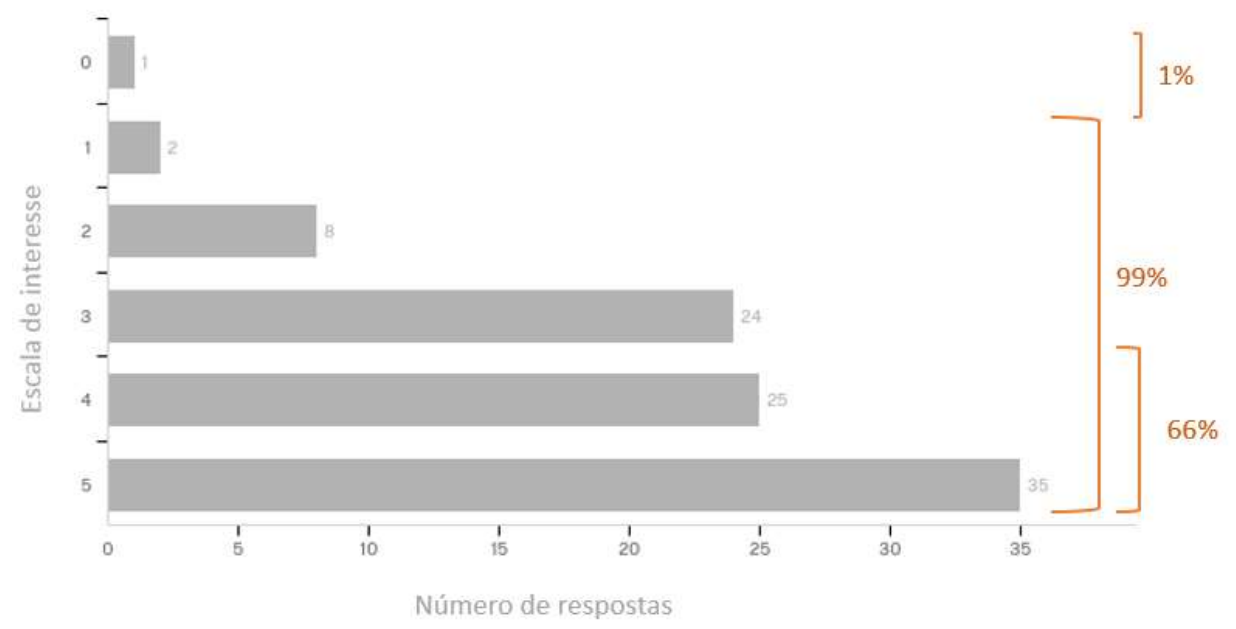

Numa escala de 0 a 5 , onde 0 é totalmente sem interesse e 5 é extremamente interessado, qual o seu interesse por tecnologia e inovação?

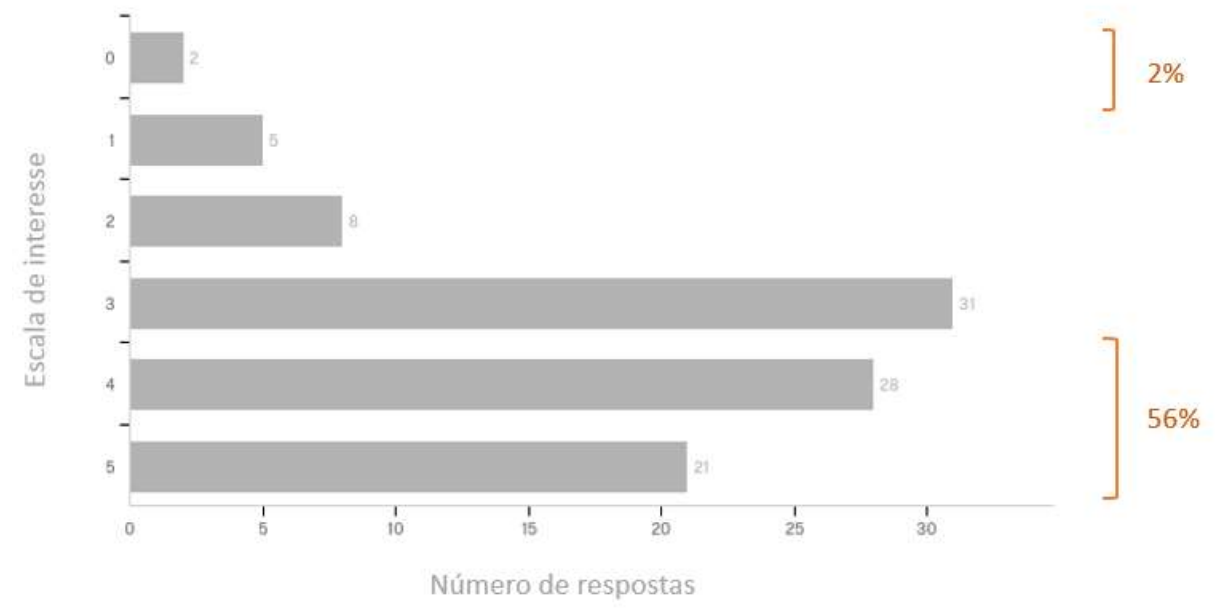

Numa escala de 0 a 5 , onde 0 é totalmente sem interesse e 5 é extremamente interessado, qual o seu interesse por moda, tendeências e marcas do momento?

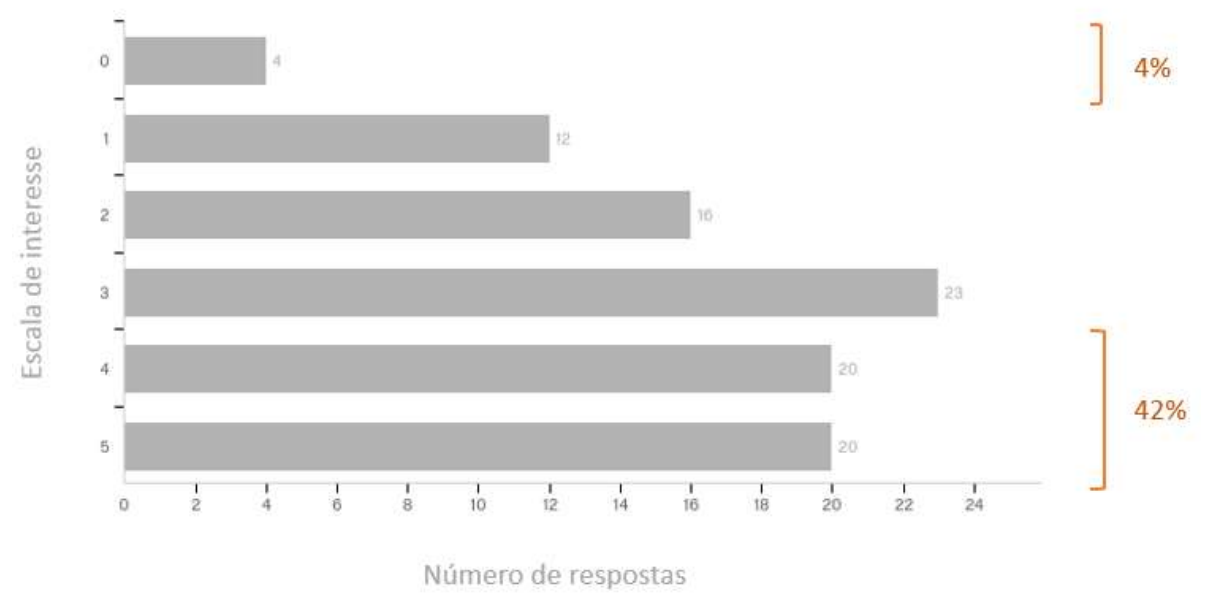

Fonte: Elaborado pelo autor 
Os gráficos acima, apontam e comprovam que responsabilidade socioambiental é um tema de muito interesse do público, pois apenas um $1 \%$ dos intervisitados respondeu que não tem interesse no assunto. Os outros dois temos apontados na pesquisa também são de interesse dos indivíduos, porém, menos que o tema social.

\subsubsection{Relação com o futebol}

Como o estudo de interesse desse trabalho é o patrocínio de futebol, a pesquisa também se preocupou em entender a relação do público com esse esporte.

Foi verificado que $75 \%$ dos interrogados se interessam por futebol e interagem com um time. Dentre todos os entrevistados, $37 \%$ já foi ou é sócio de um clube. O que demonstra que o futebol é um tema que agrada e está muito presente na vida dos brasileiros.

Outra questão estudada foi a periodicidade de compra de produtos licenciados do clube do entrevistado, caso ele torça para algum clube. O objetivo dessa pergunta foi entender a intensidade que os interrogados se dispõe a investir no seu clube de futebol e a periodicidade que isso acontece. Seguem abaixo os resultados da pesquisa:

\section{Gráfico 3: Relacionamento do público com o futebol}
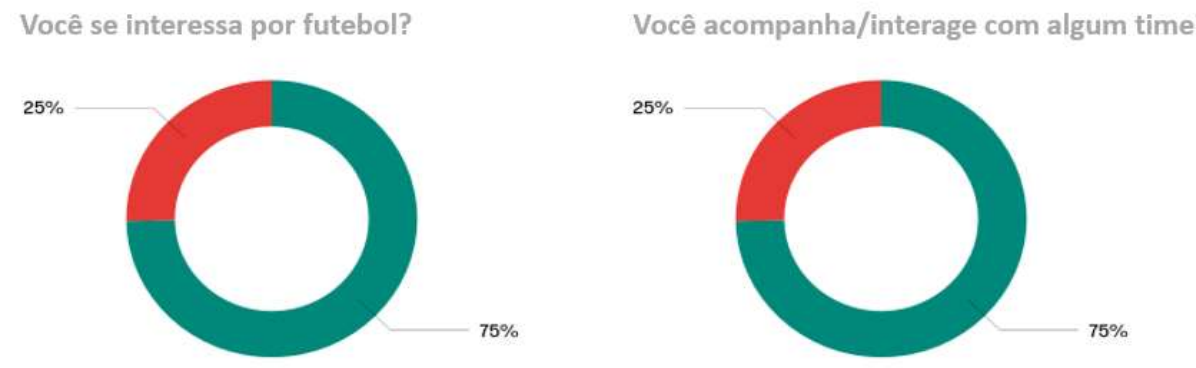
Você já foi ou é sócio de algum time?
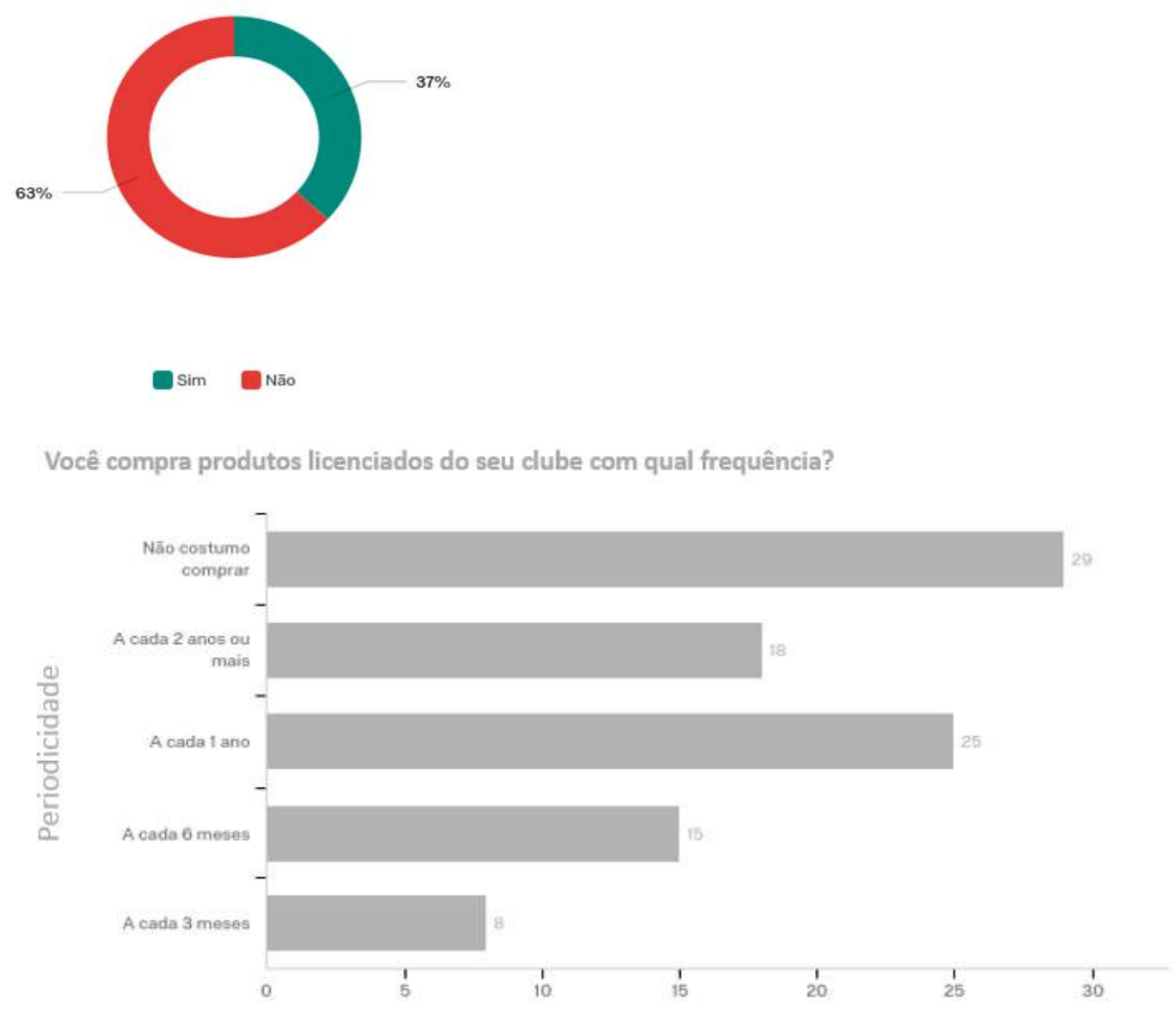

Número de respostas

Fonte: Elaborado pelo autor

Pode-se observar nos gráficos acima que o relacionamento do público com o futebol é muito grande. Outro ponto de destaque, visto no último gráfico, é a frequência de compra de produtos licenciados, em que mais de $50 \%$ do público investe em novos produtos do time de coração todo ano. Informação importante para comprovar que com uma boa gestão de marketing é possível alavancar as vendas de camisas e outros produtos.

\subsubsection{Propostas aos entrevistados}

Com o objetivo de conhecer melhor uma amostra da sociedade, no que se refere ao envolvimento e sensibilização com causas sociais, a pesquisa propôs algumas situações para os entrevistados, em que eles responderam de acordo com a sua crença, valores e opiniões. 
O resultado dessas propostas serviu como fundamento para o trabalho ser concluído atingindo seu objetivo.

As propostas foram as seguintes:

- Considere que você não torce para nenhum clube de futebol. Te apresento dois times da sua região, com as cores iguais e no mesmo patamar de tradição e conquistas, sendo a única diferença o patrocínio máster, que estampará a camisa. O Time $A$, será patrocinado pela Apple (Grande empresa privada que atua em benefício próprio e particular) e o Time B pela Sonhar Acordado (Uma ONG sem fins lucrativos, que busca transformar a vida de crianças carentes). O Time A receberá da Apple 20 milhões para estampar a sua marca, enquanto o Time $B$ cederá gratuitamente 0 seu espaço na camisa para a ONG. Para qual time você torceria?

\section{Gráfico 4: Resultado proposta 1}

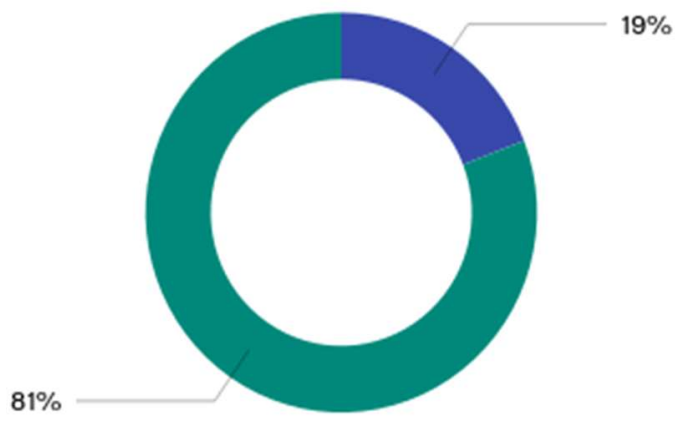

Dtimea D Time B

\section{Fonte: Elaborado pelo autor}

O Time B, patrocinado pela OGN Sonhar Acordado, foi o mais votado com $81 \%$ dos votos. Diante desse percentual expressivo, pode-se concluir que o público valoriza mais um patrocínio de uma organização que luta pelas causas sociais do que de uma grande empresa privada, mesmo se que seja uma marca influente e que vá investir de antemão milhões no clube. 
- Qual patrocínio te motivaria mais a comprar uma camisa de time?

\section{Gráfico 5: Resultado proposta 2}

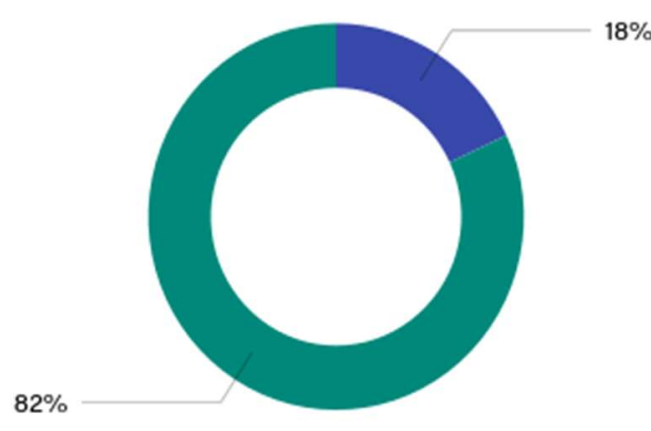

Apple ONG Sonhar Acordado

Fonte: Elaborado pelo autor

O gráfico acima aponta uma oportunidade de aumento de venda de camisas quando o clube é patrocinado por uma instituição do meio social. Visto que $82 \%$ dos entrevistados se motivam mais a comprar uma camisa de time quando este é patrocinado pela ONG.

- Qual patrocínio te motivaria mais a se tornar sócio torcedor do time?

\section{Gráfico 6: Resultado proposta 3}

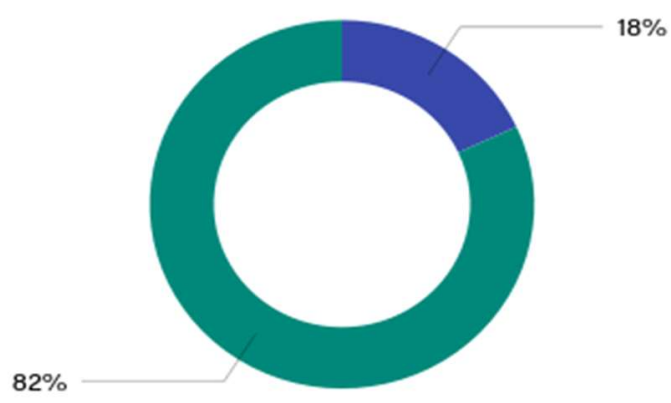

Apple

ONG Sonhar Acordado

Fonte: Elaborado pelo autor 
Pelo resultado da proposta 3, fica evidenciada a possibilidade de aumentar o quadro de sócios quando o clube é patrocinado por uma empresa do terceiro setor.

- Se o seu time cobrasse um pouco mais caro na camisa e revertesse essa quantia em doação para uma ONG, você estaria disposto a comprar a camisa?

\section{Gráfico 7: Resultado proposta 4}

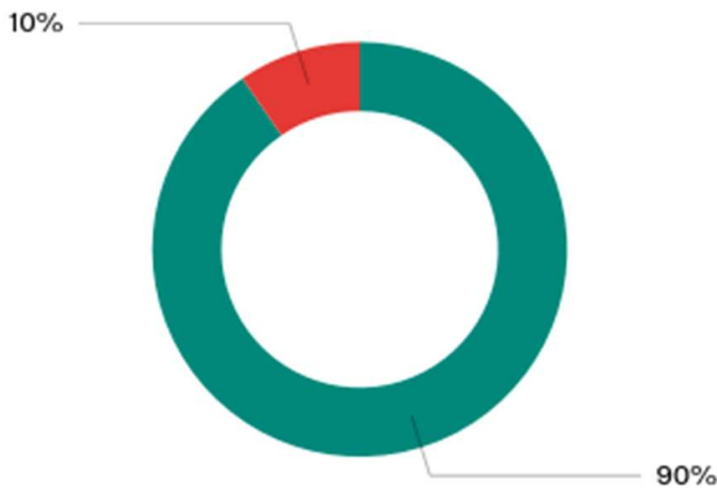

Sim $\square$ Nāo

\section{Fonte: Elaborado pelo autor}

Visto que $90 \%$ do público se dispõe a pagar mais caro na camisa do seu clube, quando ele pratica uma ação solidária, pode-se afirmar que a preocupação social do clube é positiva tanto para a causa apoiada quando para o clube, que pode aumentar as suas vendas de camisa e melhora a sua imagem para a sociedade. 
- Se o seu time doasse parte da arrecadação dos sócios para uma ONG, você se sentiria mais motivado a ser sócio?

\section{Gráfico 8: Resultado proposta 5}

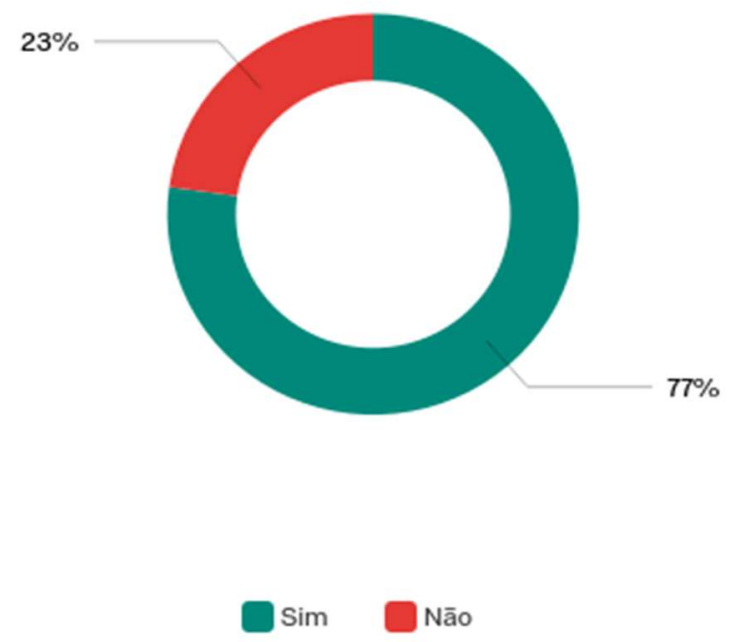

Fonte: Elaborado pelo autor

Assim como no resultado da proposta 4, a proposta 5 também provou que o clube pode se beneficiar com a prática de campanhas sociais, pois $77 \%$ dos entrevistados responderam que se sentem motivados a se tornarem sócios do clube se ele doar parte da arrecadação da receita de sócios.

- Na sua opinião os clubes de futebol deveriam realizar mais ações voltadas para a responsabilidade social?

\section{Gráfico 9: Resultado proposta 6}

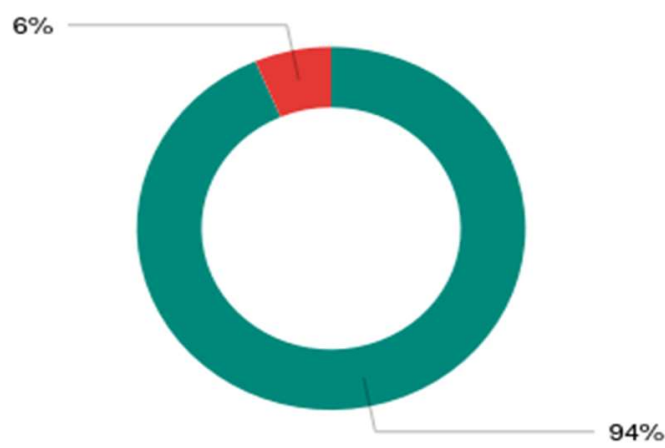

Sim Nāo 
Essas respostas evidenciam um o apelo dos entrevistados a causas sociais, visto que em todas as respostas, com exceção da proposta seis (gráfico 8), mais de $80 \%$ dos entrevistados responderam a favor da causa. Vale destacar o resultado da proposta nove, expresso no gráfico 9 , em que $94 \%$ dos entrevistados pensam que os clubes devem investir mais em ações de responsabilidade social.

\subsection{Análise dos resultados}

\subsubsection{Maior apelo pelo social}

Analisando o resultado das respostas da pesquisa de campo, verificou-se uma grande preocupação dos indivíduos com questões sociais. Além de preocupação, também ficou visível que esses indivíduos estão mais dispostos a investir seu tempo e recursos financeiros a times que estão mais preocupados com causas nobres de âmbito social.

\section{Gráfico 10: Evidências do apelo social}

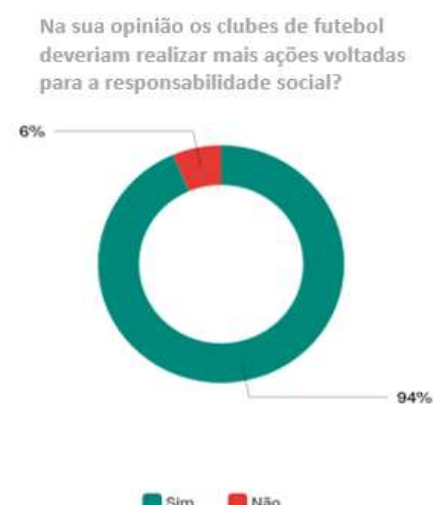

- $\operatorname{conào}$

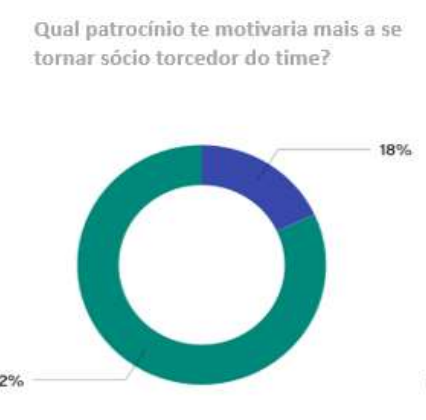

- Apple ONG Sonhar Acordado
Qual patrocinio te motivaria mais a comprar uma camisa de time?

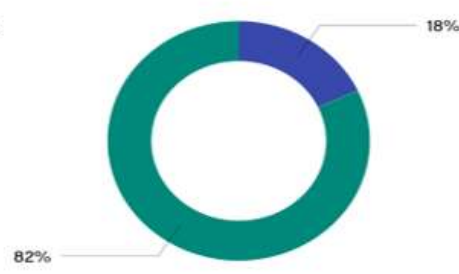

- Apple ONG Sonhar Acordado

\section{Fonte: Elaborado pelo autor}

Todas as perguntas acima serviram para entender e mensurar o nível de apelo do público com as questões sociais. O resultado foi satisfatório, pois em todas as perguntas mais de $80 \%$ das respostas foram congruentes a causa social. 


\subsubsection{Alavancagem das receitas de sócio e vendas de camisa}

A pesquisa também permitiu concluir que as pessoas se sentem mais motivadas a comprar produtos oficiais e se filiarem a um clube quando ele é patrocinado por uma organização do terceiro setor. O que significa dizer que com esse patrocínio um time consegue alavancar suas vendas de produtos e aumentar seu quadro de sócio. Obtendo assim, um crescimento de suas receitas.

Mas para isso acontecer não basta somente o clube fechar a parceria com a organização, ele deve também utilizar a ferramenta de marketing esportivo para explorar os benefícios dessa parceria e consequentemente terá o crescimento de receita.

A pesquisa apresentou para o público entrevistado duas ações de marketing, uma para alavancar a venda de camisas, em que o clube irá aumentar um pouco o valor da camisa e em contrapartida esse delta do aumento será revertido para uma ONG, e outra para aumentar a filiação de sócios, em que o clube doaria uma pequena parte da arrecadação para a ONG.

Ambas as ações tiveram um sucesso grande com o público entrevistado, em que $90 \%$ estariam mais dispostos a comprar a camisa e $77 \%$ a se tornarem sócios, como ilustra o gráfico a seguir:

\section{Gráfico 11: Resultado das ações de marketing}
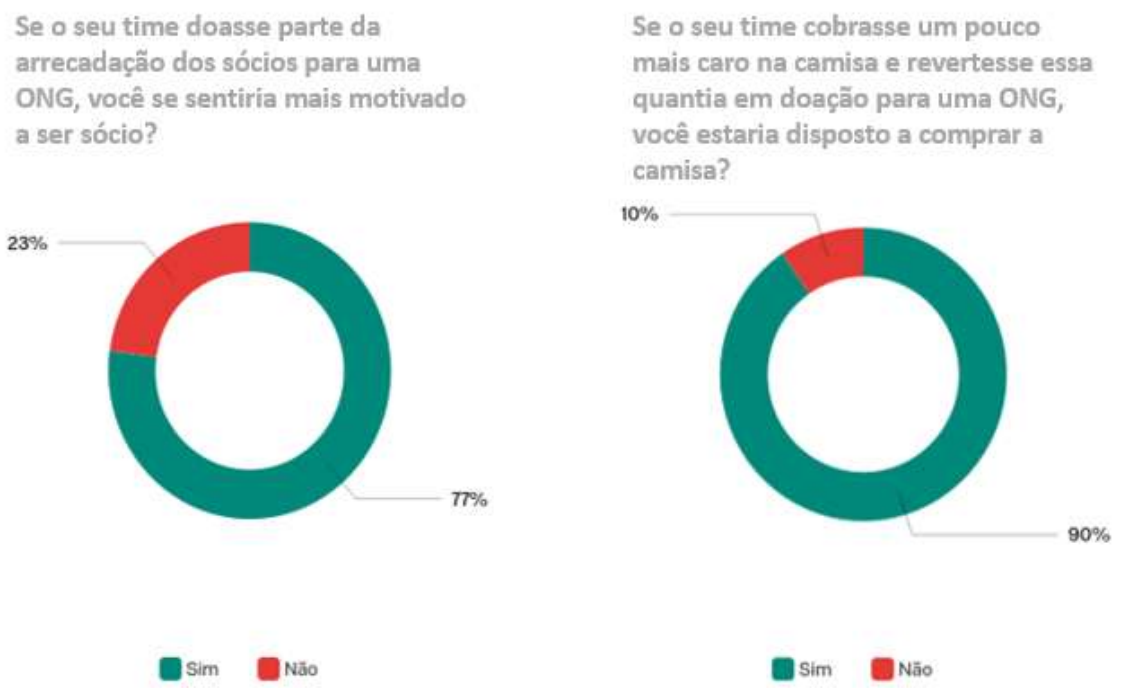

Fonte: Elaborado pelo autor 


\subsubsection{Patrocínio do terceiro setor é viável e rentável.}

O estudo dos artigos mostrou que a receita da venda de produtos é menor do que a de patrocínio, porém não fica muito distante. E a receita de sócios tem uma representatividade igual ou muito próxima a de patrocínio.

A pesquisa de campo apontou que é possível aumentar consideravelmente o número de sócios e a venda de camisas, com o patrocínio do terceiro setor.

Cruzando essas duas informações pode-se afirmar que com um trabalho bem feito de marketing esportivo por tarde dos gestores do clube, o patrocínio de uma equipe do terceiro setor é viável e rentável tão quanto o patrocínio de uma empresa grande do segundo setor, pois a verba de patrocínio que o clube deixou de ganhar, ele consegue capturar através do aumento do número de sócios e da venda de camisas. 


\section{Conclusões e recomendações para novos estudos}

Este estudo contribuiu para analisar e entender um pouco sobre uma importante ferramenta do marketing, o patrocínio. Foram apresentados conceitos, números e aplicações no futebol brasileiro dos dias atuais.

O trabalho propôs analisar um tipo de patrocínio pouco comum e comprovar sua viabilidade, para isso foi realizada uma pesquisa de opinião e estudo de artigos do meio esportivo.

Dentre toda bibliografia estudada, os autores que mais contribuíram foram Philip Kotler, Antonio Afif, Ernani Contursi, Julio Cesar Santos, Vivian Oswald e Amir Somoggi.

Com as informações do mercado obtidas em artigos de especialistas, pesquisadores e estatísticos, mais os resultados da pesquisa de opinião, foi possível concluir o estudo provando que vale a pena para o clube ser patrocinado por uma empresa do terceiro setor, sem receber a verba da venda do espaço da camisa.

\subsection{Sugestões e recomendações para novos estudos}

Esse trabalho serve como bom ponto de partida para um estudo mais profundo do tema. Recomenda-se para estudos futuros, uma análise mais prática do caso, ou seja, realizar entrevistas com agentes do futebol e do marketing esportivo, pessoas que vivem o dia a dia dos clubes e conhecem a fundo as práticas de patrocino, e realizar testes de mercado. 


\section{Referências Bibliográficas}

AFIF, A. A Bola da Vez - O marketing esportivo como estratégia de sucesso. São Paulo: Editora Infinito, 2000.

Agrupamento de Escolas Dr. Serafim Leite, SlidePlayer, Disponível em: http://slideplayer.com.br/slide/1876737/ > Acesso em: 5 mai.2017

CAPELO, R. R\$ 5 bilhões em faturamento - por que o futebol brasileiro arrecadou tanto em 2016, Época, mai. 2017. Disponível em:

http://epoca.globo.com/esporte/epoca-esporte-clube/noticia/2017/05/r-5-bilhoes-

em-faturamento-por-que-o-futebol-brasileiro-arrecadou-tanto-em-2016.html

> Acesso em: 21 abr. 2017.

CONTURSI, E. Marketing Esportivo. Volume I, Rio de Janeiro: Sprint, 1991.

ESCÓSSIA, C. O que é: Primeiro, segundo e terceiro setor, Blog de Carlos Escóssia, Disponivel em: http://www.carlosescossia.com/2009/10/o-que-eprimeiro-segundo-e-terceiro.html > Acesso em 9 mai. 2017

Fifa divulga números de audiência da Copa de 2014: mais de 1 bi na final, Globo esporte, dez. 2015. Disponível em: http://globoesporte.globo.com/futebol/copado-mundo/noticia/2015/12/fifa-divulga-numeros-de-audiencia-da-copa-de-2014mais-de-1-bi-na-final.html > Acesso em: 21 abr. 2017.

Futebol é a maior paixão dos brasileiros, lbope, Disponível em: http://www.ibope.com.br/pt-br/noticias/Paginas/Futebol-e-a-maior-paixao-dosbrasileiros.aspx > Acesso em 21 abr. 2017

IBOPE Repucom apresenta resultados de patrocínio esportivo entre as seleções de futebol, Kantar ibope media, mar. 2014. Disponível em: https://www.kantaribopemedia.com/ibope-repucom-apresenta-resultados-de-

patrocinio-esportivo-entre-as-selecoes-de-futebol/ > Acesso em: 21 abr. 2017.

Jogadores doarão escudo do Vitória em campo, AD News, Disponível em: http://adnews.com.br/publicidade/jogadores-doarao-escudo-do-vitoria-emcampo.html > Acesso em: 7 abr.2017

KOTLER, P. Administração de Marketing - $10^{\text {a }}$ Edição, São Paulo: Prentice Hall, 2000.

MCCARTHY, N. LISTAS 15 atletas que mais ganham com patrocínio no mundo, Forbes, ago. 2015. Disponível em: http://www.forbes.com.br/listas/2015/08/15-atletas-que-mais-ganham-compatrocinio-no-mundo/ > Acesso em 25 abr. 2017

MELO NETO, Francisco Paulo de. Marketing Esportivo - 0 esporte como ferramenta do marketing moderno. Rio de Janeiro: Best Seller, 2013. 
Modelos de patrocínio esportivo no futebol, Universidade do Futebol, ago. 2007. Disponível em:

http://universidadedofutebol.com.br/modelos-de-patrocinio-esportivo-no-futebol/

> Acesso em: 14 abr. 2017.

MOTTA, M.B., MANASSÉS, D.M., SANTINELLO, J. MARKETING ESPORTIVO: OS PATROCÍNIOS NO FUTEBOL

http://www.designbrasil.org.br/entre-aspas/marketing-esportivo-os-patrociniosno-futebol/ > Acesso em: 14 abr. 2017.

Os patrocínios mais caros do mundo, Fox Sports, Disponível em: https://www.foxsports.com.br/photos/7849/4-os-patrocinios-mais-caros-do-mundo $>$ Acesso em 25 abr. 2017

OSWALD, V. O Brasil movimenta apenas $2 \%$ do mercado da bola, O Globo, 2014. Disponível em: http://oglobo.globo.com/brasil/brasil-movimenta-apenas-2do-mercado-da-bola-13026765 > Acesso em: 04 mai. 2017.

REZ, R. Tipos de Marketing: conheça as principais áreas e suas funções, Nova escola de Marketing, mai. 2014. Disponível em: http://www.novaescolademarketing.com.br/marketing/tipos-de-marketing/ > Acesso em 25 abr. 2017

SANTOS, S. JC. O conceito e a natureza do patrocínio, Administradores.com.br, nov. 2010. Disponível em: http://www.administradores.com.br/artigos/marketing/o-conceito-e-a-natureza-dopatrocinio/49641/ > Acesso em: 14 abr. 2017.

SETYON, C. Indústria do esporte movimenta US\$ 1 trilhão no mundo http://www.amcham.com.br/eventos/regionais/amcham-sao-

paulo/noticias/2012/industria-do-esporte-movimenta-us-1-trilhao-no-mundo

$>$ Acesso em 5 abr.2017.

SOMOGGI, A. Entendendo as finanças dos clubes brasileiros em 2016, Lance, mai. 2017. Disponível em: http://blogs.lance.com.br/somoggi/entendendoas-financas-dos-clubes-brasileiros-em-2016/ > Acesso em: 04 mai. 2017.

ZIRPOLI, C. Os patrocínios privados e estatais dos clubes da Série A de 2017, via Ibope, Blog Diário de Pernambuco, mar. 2017, Disponível em: http://blogs.diariodepernambuco.com.br/esportes/2017/03/01/os-patrociniosprivados-e-estatais-dos-clubes-da-serie-a-de-2017-via-ibope/ > Acesso em: 25 abr. 2017.

ZIRPOLI, C. Os bilhões do planeta bola, Blog Diário de Pernambuco, mai. 2010, Disponível em: http://blogs.diariodepernambuco.com.br/esportes/2010/05/10/osbilhoes-do-planeta-bola/ > Acesso em: 25 abr. 2017

ZIRPOLI, C. Os 20 clubes mais ricos do mundo, com o Manchester United no topo após 12 anos, Blog Diário de Pernambuco, jan. 2017, Disponível em: http://blogs.diariodepernambuco.com.br/esportes/2017/01/23/os-20-clubes-maisricos-do-mundo-com-o-manchester-united-no-topo-apos-12-anos/ > Acesso em: 25 Abr. 2017 
Magnus expande ações de marketing no esporte, Grandes Nomes da Propaganda, Disponível em: http://grandesnomesdapropaganda.com.br/anunciantes/magnus-expande-acoesde-marketing-no-esporte/ > Acesso em: 7 abr. 2017 


\section{Anexo 1}

\section{Questionário aplicado na pesquisa e suas respostas}

O questionário foi elaborado no site Qualtrics e está disponível no link: https://qtrial2017q2az1.az1.qualtrics.com/jfe/form/SV_4MjiEqkMKhROxVz

O questionário abaixo faz parte do trabalho de conclusão de curso em Administração de Empresas da PUC-Rio, do aluno João Madeira.

1) Qual o seu sexo?

2) Qual a sua idade?

3) Numa escala de 0 a 5, onde 0 é totalmente sem interesse e 5 é extremamente interessado, qual o seu interesse por questões sociais e ambientais?

4) Numa escala de 0 a 5 , onde 0 é totalmente sem interesse e 5 é extremamente interessado, qual o seu interesse por tecnologia e inovação?

5) Numa escala de 0 a 5, onde 0 é totalmente sem interesse e 5 é extremamente interessado, qual o seu interesse por moda, tendências e marcas do momento?

6) Você se interessa por futebol?

7) Você acompanha/interage com algum time?

8) Você é ou já foi sócio de algum time?

9) Você compra produtos licenciados do seu clube com qual frequência: 
10) Agora considere que você não torce para nenhum clube de futebol. Te apresento dois times da sua região, com as cores iguais e no mesmo patamar de tradição e conquistas, sendo a única diferença o patrocínio máster, que estampará a camisa. 0 Time A, será patrocinado pela Apple (Grande empresa privada que atua em benefício próprio e particular) e o Time B pela Sonhar Acordado (Uma ONG sem fins lucrativos, que busca transformar a vida de crianças carentes). $O$ Time A receberá da Apple 20 milhões para estampar a sua marca, enquanto o Time $B$ cederá gratuitamente o seu espaço na camisa para a ONG. Para qual time você torceria?

11) Qual patrocínio te motivaria mais a comprar uma camisa de time?

12) Qual patrocínio te motivaria mais a se tornar sócio torcedor do time?

13) Se o seu time cobrasse um pouco mais caro na camisa e revertesse essa quantia em doação para uma ONG, você estaria disposto a comprar a camisa?

14) Se o seu time doasse parte da arrecadação dos sócios para uma ONG, você se sentiria mais motivado a ser sócio?

15) Na sua opinião os clubes de futebol deveriam realizar mais ações voltadas para a responsabilidade social? 